\title{
PRELIMINARY COMPARATIVE STUDY ON PATIENTS WITH MYCOSES - A COMPARISON BETWEEN CANDIDA AND OTHER FUNGAL INFECTIONS
}

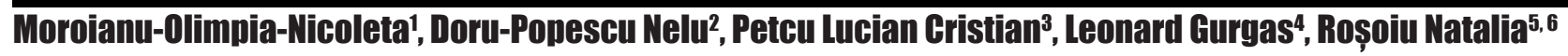

${ }^{1}$ Organizational Institute of Doctoral Studies - University "Ovidius" of Constanţa

${ }^{2}$ Naval Medical Centre Constanta, Dermatology

${ }^{3}$ Faculty of Denstristry, University "Ovidius" of Constanta

${ }^{4}$ Faculty of Medicine, University "Ovidius" of Constanta

${ }^{5}$ Academy of Romanian Scientists, Bucharest

${ }^{6}$ Emeritus Professor, Faculty of Medicine, University "Ovidius" of Constanta

Olimpia-Nicoleta Moroianu

Aleea Topolog, $n r .2$, bl. H 8, sc. C, ap.58, et. IV, Constanța, Romania email:olimpia1976@yahoo.com phone: +40764808412

\begin{abstract}
Abstract. The study aims at highlighting the differences in the main statistical parameters between two groups of patients diagnosed with mycosis, while monitoring the frequency of association with various other conditions.
\end{abstract}

Keywords: statistical parameters, fungi, mycosis, Candida

\section{Introduction}

Mycosis is a condition commonly found in medical practice. They occur due to contamination with fungal agents in three ways: infection from an ill person, from a sick animal, or transformation of saprophytic fungi into certain environmental and environmental conditions. They are known to about 100000 fungi, most of them saprophytes.

Fungi develop in the corneum layer of the skin, nail, and hair, especially in a moist environment, away from sunlight (1).

The fungi can be unicellular and multicellular, also.
The reproduction of fungi is accomplished through spores (2).

Depending on the location of the fungal infection, we classify mycosis as follows: 1 . Superficial mycosis and deep mycosis (1).

Superficial mycoses are a prevalent dermatological pathology. These are produced by two major groups of fungi, yeasts, and dermatophytes (tinea infections or ringworm). The former appears by a change in the microbiota leading to a proliferation of yeasts, and the latter are exogenous infections transmitted by an animal or another person. (3).

The genus Candida is a complex and polymorphic genus, comprising over 160 species. 
Appropriate teleommorphic forms are grouped into 13 distinct genres, proving that the Candida genus is an artificial taxonomic association of unrelated species.

Candida can be albicans, african, boidinii, catenulata, chiropterorum, colliculosa, curvata, cifrari, dubliniensis, famata, glabrata, globosa, guilliermondii, hemulonii, holmii, inconspicua, lambic, lipolytic, lusitaniae, magnoliae, melibiosic, membranofaciens, norvegensis, norvegia, parapsilosis, pelliculosa, pulcheririma, rugosa, maris, pararugosa, tropicalis, utilis, valida, viswanathii, zeylanoides (4).

The most commonly involved in human pathology is Candida albicans. It propagates by sprouting and produces elongated (pseudohife) and, occasionally, hay. The ability to exist both as a hippie and as a leaven is called dimorphism. In its yeast form Candida is a commensal germ, and when it forms pseudohay or hay has a pathogenic role (2).

Generally favoring factors should be mentioned: diabetes mellitus, congenital or acquired cellular immune deficiency states, broad spectrum antibiotic therapy, antitrychomonasic therapy, iron deficiency, endocrine diseases. Local favors are involved: friction and maceration, contact with hydrocarbon solutions (5).

Candidiasis can be located at different levels: cutaneous, oral cavity, gastrointestinal tract, genito-urinary tract. These areas can constitute, under the action of various factors, true Candida reservoirs, thus speeding up the appearance of manifestations.

Candida albicans can cause superficial infections of the mucous membranes and skin and deep infections of the internal organs (endocarditis, meningitis, etc.) under conditions of immunodepression (2).

The extreme complexity of patients and the growing diversity of pathogenic fungi are major challenges for improving diagnosis, creating surveillance networks, and implementing control measures for these invasive infections (6).

Deep systemic mycoses are rare mycoses in which the entrance gate is the epidermis, but the development of lesions is produced in the dermis and hippocampus, where the parasite can invade the soft tissues and the underlying bones or can disseminate remotely (7).
Candidiasis are fairly frequent fungal infections, affecting both men and women. Candida albicans is involved in over $70 \%$ of Candidiasis cases (8). If Candida albicans enter your bloodstream, they can cause serious infections not only in your blood but in other organs as well (9).

\section{Material and method}

A number of 65 observation sheets of patients diagnosed with different forms of "candida" and a number of 40 observation sheets of patients diagnosed with different forms of "mycosis" were selected. The patients presented themselves at the St. Andrew County Hospital in Constanta from May 2017 until to the middle of January 2018. The main passport data was entered in a SPSS 23 statistical program to obtain comparative graphs related to living (rural/ urban) conditions, sex, age, biochemical and hematological investigations. Important data was also obtained by comparing the association with other diagnoses specified in the medical documentation.

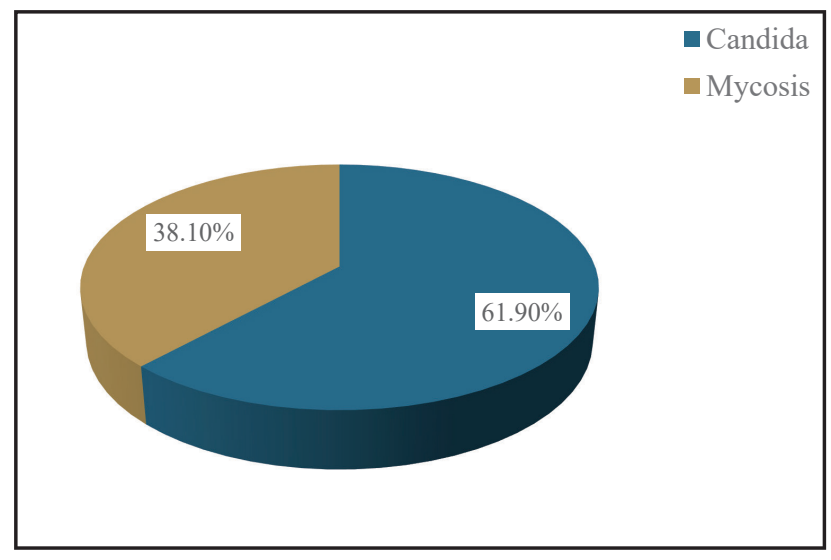

Figure 1. Representation Pie for the distribution of patients per lots (Candida / other mycosis)

The study enrolled 105 patients, 65 of whom were Candida (61.9\%) and 40 with Mycosis (38.1\%).

In table 1 are relataded dates referring of comparative evolution of patients who suffered of candida or other mycosis. 
Table 1. Evolution of patients with candida and other mycosis

\begin{tabular}{|c|c|c|c|c|c|c|}
\hline & & \multicolumn{4}{|c|}{ Evolution } & \multirow{2}{*}{ Total } \\
\hline & & Improved & Cured & Stationary & Worse & \\
\hline \multirow{2}{*}{ Candida } & Count & 58 & 3 & 3 & 1 & 65 \\
\hline & $\%$ Of Total & $89.23 \%$ & $4.62 \%$ & $4.62 \%$ & $1.54 \%$ & $100.00 \%$ \\
\hline \multirow{2}{*}{ Mycosis } & Count & 39 & 0 & 1 & 0 & 40 \\
\hline & $\%$ Of Total & $97.50 \%$ & $0.00 \%$ & $2.50 \%$ & $0.00 \%$ & $100.00 \%$ \\
\hline
\end{tabular}

\section{Discussions}

In both groups the prevalence of male sex was observed $(34.3 \%$ and $21 \%$ respectively, compared to $27.6 \%$ and $18.1 \%$ respectively for females). Both populations show the prevalence of urban origin $(52.4 \%$ and $27.6 \%$ respectively, compared to $9.5 \%$ and $10.5 \%$ respectively in rural areas). In terms of age, the majority of the candidates were children ( $33 \%$ vs. adults $32 \%)$, and no more children were registered in the «other mycosis» group.

It observed in this study that only a few of them managed to heal.

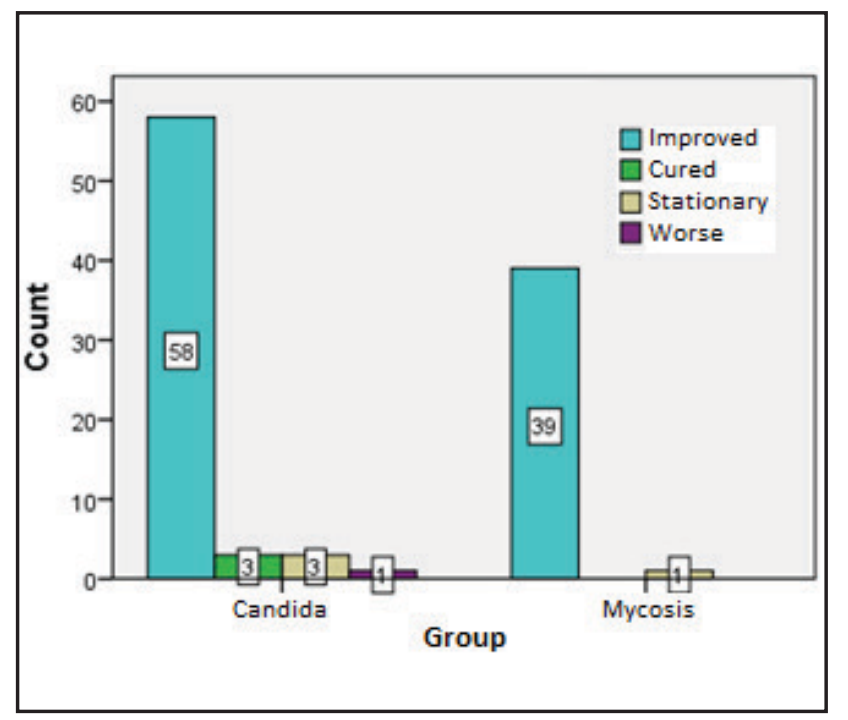

Figure 2 Representation in Columns of the evolution of patients with Candida lother mycosis lots

In this analysis, we also took into account the other diseases of the patients to understand why a part of them heals more easily, another part heals more slowly and a part does not or are worse.

Regarding the association with other conditions, it is clear that the group of patients diagnosed with "mycosis" associates more affections that may be directly or indirectly related to those mycosis than the "thrush" group, as follows: venous insufficiency $(40 \%$ $1.5 \%)$, hypertension ( $37 \%$ versus $13.8 \%$ ), type 2 diabetes (17.5\% vs. $7.7 \%$ ), chronic ischemic heart disease $(12.5 \%$ versus $6.2 \% \quad 17.5 \%$ vs. $3.1 \%)$. In contrast, there is an increase in the association of pneumonia cases with the "thrush" group (18.5\%) against the "mycosis" group $(2.5 \%)$ the last observation can be explained as a consequence of the antimicrobial effect of antibiotics on the saprophytic microbial flora, protective against the development of candida.

\section{Conclusions}

In terms of biochemical and hematological investigations, there are significant differences in the mean values between the two groups, as follows: in the "thrush" group the mean lymphocyte values (17.64 versus $\left.11.9210^{3} / \mu \mathrm{L}\right)$, the platelets $\left(310.03\right.$ vs. $\left.247.0710^{3} / \mu \mathrm{L}\right)$, AST ( 28.70 vs. $22.53 \mathrm{U} / 1)$; in the group "mycosis" there are higher mean eosinophil values (1282 versus $67510 \mu \mathrm{g} / \mathrm{dl})$, serum glucose (104.95 vs. $95.64 \mathrm{mg} / \mathrm{dl})$, neutrophils (35.75 versus $\left.29.9010^{3} / \mu \mathrm{L}\right)$, urea (40.24 vs. $\left.29.97 \mathrm{mg} / \mathrm{dl}\right)$. By comparing these values with one another, it can be concluded that changes in biological constants in other mycoses are more important, more serious, than those recorded to candidates.

\section{References}

1. Diaconu JDC, Nica D, Popescu M-A, Dinu C-C. Dermato-venerologie : pentru studentii facultatilor de stomatologie Bucuresti Editura Didactica si Pedagogica; 1999.

2. Forsea D, Popescu R, Popescu M. Compendiu de dermatologie şi venerologie. Bucuresti: Editura Tehnica; 1996.

3. Gubelin W, de la Parra R, Giesen LF. Micosis superficiales. Médica Clínica Las Condes. 2011:22:804-12. 
4. Buiuc D, Negut M. Tratat de microbiologie clinica: Editura Medicala; 2008.

5. Bucur G, Opris DA. Boli dermatovenerice : Enciclopedie. 2, editor. Bucureşti: Editura Medicală Naţională; 2002.

6. Quindós G. [Epidemiology of invasive mycoses: A landscape in continuous change]. Rev Iberoam Micol. 2018:35(4):171-8.

7. Dimitrescu A. Dermatologie. Bucuresti: Editura Medicala Nationala; 2002.

8. Diaconu D-JC, Dana Nica M-AP, Fratea C-C. Dermato-venerologie : pentru studentii facultatilor de medicina generala, medici rezidenti si medici de familie. Bucuresti: Editura Didactica si Pedagogica; 1999.

9. Berman J. Candida albicans. Current Biology. 2012;22(16):R620 